\section{"The Offspring of Drunkards": Gender, Welfare, and the Eugenic Politics of Birth Control and Alcohol Reform in the United States}

\author{
Lauren MacIvor Thompson
}

Keywords: Alcohol, Eugenics, Prohibition, Pregnancy, Birth Control

Abstract: The social politics of women's alcohol use is controversial given current debates over maternal-fetal health, fetal alcohol syndrome, and debates about welfare. Exploring the early twentieth century intersections of Prohibition, birth control reform, and alcohol politics reveals the historical roots of current recommendations surrounding women, alcohol, and public assistance.

$\Delta$ lcohol use has always been a persistent social concern in the United States, rife with the stigmas of laziness, poverty, and dependence that endure alongside its more recent medicalization. But the potential for pregnancy adds yet another layer of complexity regarding public health policy on women and alcohol use. In summer 2021, the draft Global Alcohol Action Plan 2022-2030 released by the World Health Organization advised, "Appropriate attention should be given to ... prevention of drinking among pregnant women and women of childbearing age." In doing so, they joined the Centers for Disease Control in the United States, who in 2016 had also officially recommended that sexually active women refrain from drinking unless using contraception. In both cases, the recommendations were met with public skepticism, with critics noting that men who consume alcohol were not mentioned in either case (even though recent studies have shown an increase in birth defects related to men's use of alcohol prior to conception). ${ }^{1}$

Despite this resurgence in awareness and controversy, the regulatory guidance on these issues is not new. Indeed, examining the historical relationship between the movement to legalize birth control and the simultaneous attempts to regulate alcohol in the twentieth century can illuminate rationales behind modern policies on alcohol and welfare reform, as well as concomitant understandings of dependency and disability. After all, public health protocol has long linked the social costs of alcohol with both the protection of women and fears of non-marital births or disabled children. In nineteenth-century America, much of the temperance movement's strength rested upon notions of women as victims of both male drunkenness and their responsibilities for maintaining domes-

Lauren MacIvor Thompson, Ph.D., is an Assistant Professor of History and Interdisciplinary Studies at Kennesaw State University and a Faculty Research Fellow at the Georgia State University College of Law's Center for Law, Health, and Society. 
ticity and purity. This meant that women who drank, to excess or not, were especially vulnerable to accusations that not only were they harming themselves and their families, but also damaging the feminine obligation to keep society itself moral. ${ }^{2}$ Physicians and reformers warned that women who drank could pass on the tendency toward drunkenness as well as disease, disability, and bad moral temperament to their children. Later, these concerns were reformatted with the identification of Fetal Alcohol Syndrome in the early 1970s. The recent CDC and WHO guidance extends the longstanding idea that women's responsibility for a healthy pregnancy is hers and hers alone, and that it begins before conception. ${ }^{3}$

Although much of this guidance centers on improved maternal-child health, deeper concerns about disability and dependence are underneath the surface of the concerns about alcohol and pregnancy. The connection between alcohol use, labor, and welfare dependency remains fraught and understudied, especially in the context of gender. Women with dependent children who have alcohol and substance abuse issues often encounter significant barriers in applying for and receiving federal aid. Although there is not much contemporary data to assert definitively that women with alcohol or drug dependency are more likely to be welfare recipients or unemployed, the perception that welfare itself promotes alcohol and drug use informs public thinking around federal aid programs and the need to incorporate personal responsibility as a central requirement for public assistance. ${ }^{4}$ These perceptions also extend to gendered understandings of women's roles as mothers and the social impact of non-marital births and single-parent households.

The historical context behind these ideas and polices can be partially traced to the relationship between the various factions of the temperance, birth control, and anti-Prohibition civil liberties groups of the 1920s. In the age of Prohibition, the overlapping politics of alcohol reform and the movement to legalize birth control coalesced in a shared rhetoric. Both movements associated drinking and disability together in a set of compelling arguments for the protection of the family and American society from drunken men. Both sides argued that their pursuit of laws governing the public's use of either alcohol or contraception constituted a gain for eugenics, influencing the "health, sanity, and stamina of generations yet unborn" as eugenics reformer Albert Wiggam phrased it. ${ }^{5}$ Yet temperance and birth control were not always compatible bedfellows. Their respective advocates clashed over questions of morality, health, and the public good in their simultaneous pursuits to either maintain or remove the legal prohibitions on alcohol and birth control.
Temperance had long made arguments about health and home to win Prohibition. In the antebellum period, the burgeoning anti-alcohol movement had its roots in women's general moral reform associations. Yet the temperance movement went beyond mere moral suasion, linking their fight against alcohol directly to the politics of the suffrage movement. Although not all temperance advocates were suffragists, many of them were "relatively willing to express what [reformer] Amelia Bloomer called 'a strong woman's rights sentiment" and insisted that gaining the right to vote was the most important key to accomplish their aims. By the late nineteenth century, the Women's Christian Temperance Union (founded in 1874) had become a major political force as the largest women's organization of the post-Reconstruction era. By the 1920s, it had a membership of nearly 350,000, only declining after 1933 when Prohibition was repealed. The organization taught that "alcohol is a poison; that its use breaks down the physical nature and harmfully affects the blood, the nerves, the heart, and makes the drinker an easy prey to disease ... alcohol attacks the moral nature, and its use causes an increased need of institutions for the dependent, the delinquent and the criminal classes." 6

Indeed, the WCTU attracted enormous support in their crusade against the liquor industry and cannily framed women's rights through the lens of the dangers of male vice. Men who drank failed to live up to the marital bargain that called for female subordination in exchange for physical protection and economic security. As one newspaper editor pointed out, "Many ... men believe that their wife is as much their property as their dog and horse and when their brain is on fire with alcohol, they are more disposed to beat and abuse their wives than their animals.... Every day, somewhere in the land, a wife and mother - yes, hundreds of them - are beaten, grossly maltreated and murdered by the accursed liquor traffic, and yet we have men who think women should quietly submit to such treatment without complaint."' Reformers argued that women needed protection from the violent sexual advances of drunken husbands - a situation that placed "women in a slavery worse than that of chains" by "brutal and designing men." In an age in which marital rape law did not exist, nor legal birth control, temperance and women's rights advocates insisted that alcohol contributed more than its fair share to female misery, both emotional and reproductive. The idea of "voluntary motherhood," in which women had the right to refuse their husbands' sexual advances in order to only bear children they welcomed, rested in part on women's enforcement of temperance in the home. "Woman gives birth to man; alcohol destroys 
man ... It is impossible then, that woman, better instructed, should not be the irreconcilable enemy of a poison that is destructive of her offspring" one reformer reminded her audience. ${ }^{9}$

The organized movement for Prohibition not only relied on these gendered framings, but also nativist and racist sentiments about drink. As temperance crusader Annie Wittenmyer observed in her History of the Woman's Temperance Crusade, published in 1882, "I cannot close this volume without calling attention to the relation of foreign emigration to the liquor traffic, and to crime and pauperism ... more than two-thirds of the entire liquor business is in the hands of a low class of foreigners, although the entire foreign population of the country constitutes less than one-sixth." ${ }^{10}$ The WCTU, with their motto, "For God and home and native land," told its members that the "incoming tide from the old world" was leaving its "vicious portions in the city centers," and to tell the foreign-born, "If you don't like our institutions, take the first boat and go home."11

The dangers that alcohol presented in the form of violent husbands and drunken immigrant mobs were also neatly incorporated into fears about the larger effects of alcohol on the health of future generations. The popularization of the theory of eugenics provided a persuasive scientific framing for publicizing alcohol's dangers to heredity. Eugenics first made its debut in 1865 after the British scientist Francis Galton (who also happened to be Charles Darwin's second cousin) published his essay "Hereditary Talent and Character" in Macmillan's Magazine. The paper argued that humans could control and improve their offspring's mental qualities and "natural ability" through picking partners as carefully as breeders did for livestock. ${ }^{12}$

Ideas about heredity had long been part of scientific understandings of reproduction and inheritance of traits, but the idea that humanity could breed deliberately for particular traits was new. Galton did not use the word "eugenics" (derived from the Greek word eugenes, meaning "good in birth,") until 1883 in his book Inquiries into Human Faculty and Its Development and would define the term succinctly in 1904 for the American Journal of Sociology as "the science that which deals with all influences that improve the inborn qualities of a race; also with those that develop them to the utmost advantage." ${ }^{13}$ As Paul Lombardo has noted, "... it is difficult to describe all the things that eugenics meant to the public." A concept that "became concrete in a variety of ways, from political movements to voluntary social programs" and beyond into restricting reproduction of the unfit, eugenics came to mean different things to different groups. ${ }^{14}$

For eugenic reformers, they speculated on various (and often competing) theories about the relationship between alcohol and soft and hard heredity. Discussion about the dysgenic effects of liquor on women and children proliferated, as newspapers and journals trumpeted the results of eugenic family studies in which hordes of unwanted children were born to drunkard parents. As one report concluded, "This fact of inherited disease is a terrible contradiction of the argument that a man has a right to drink if he wants to." ${ }^{15}$ Physicians like William Healy theorized that the alcohol circulated through membranes of a pregnant women's womb and entered into the fetus' developing brain, bathing its cells in alcoholic poison. He noted that the "drinking mother stands a very good chance, by all accounts, of bringing forth children with defective or unstable nervous systems. We know the relation, in turn, of these abnormalities to inefficiency and to criminalism." Healy also noted the Lamarckian nature of alcohol's general immoral effects, observing that often "there was so much else that might account for a child's bad conduct" that it was often difficult to tell if alcohol was even the main factor. ${ }^{16}$

Indeed, for many researchers, the question of exactly how alcohol affected offspring remained unclear. "Does alcohol affect the germ plasm injuriously, producing hereditary defects, or does it have a selective effect, as some of held, killing off the weaker germ cells and allowing only the better to survive?" wondered University of Pennsylvania geneticist Phineas Whiting. He explained, "In the former case it would be dysgenic, in the latter eugenic. Hence, is a reformed drunkard more eugenic, or less so than a man who has always been a total abstainer?"17 Once Prohibition became the law of the land, eugenicists and physicians proceeded to divide themselves into both "dry" and "wet" camps to debate the true impact of alcohol on racial degeneracy alongside the relative virtues (or lack thereof) of the Eighteenth Amendment. ${ }^{18}$ Yet as Janet Golden has observed, for nineteenth and early twentieth-century social critics, "It was not the method by which alcohol did its damage but the damage it did that captivated their interest. Whether children suffered from poor heredity, poor parenting, poor living conditions...or from their own alcohol habit mattered less than the fact that they were liable to become disorderly and dependent citizens." 19

The Women's Christian Temperance Union embraced not only the politics of alcohol, but also employed the new science of eugenics as a weapon in their political quest to eliminate alcohol in society. They formed their own "Department of Heredity" and a Bureau of Hereditary Statistics, which served as a research data clearinghouse. They also published their own Journal of Heredity, frequently reprinting nearly all of Francis Galton's early essays and addresses on 
eugenics and setting up the dictates of Galtonian-influenced research programs. ${ }^{20}$ Additionally, secondary school temperance literature published by the WCTU's "Department of Scientific Instruction" explained the workings of hereditarian thought to students, and warned of the social consequences of parents' transmittal of liquor-disordered bodies and minds to their children. ${ }^{21}$ For the most part, the WCTU's understanding of alcoholism rested on the Lamarckian idea of soft heredity, in which a person's bad environment and bad choices could then be passed on to their offspring. In other words, as WCTU literature put it, "Sometimes one is sick or suffers very much because of wrong things that his parents or grandparents did."22 Heredity was thus understood as an unfixed process, and the popularity of Lamarckian thought ultimately had the effect of bolstering the importance of the WCTU's efforts at social reform.

By the 1920s, the emergence of the birth control movement would further alter the debates over heredity and its associated connection with the politics of alcohol and Prohibition. Once widely available, birth control devices and literature had been illegal in the United States for decades. Vice-reformer Anthony Comstock, who had established his New York Society for the Suppression of Vice (NYSSV) in 1872, had then successfully persuaded Congress to pass the "Comstock Postal Act" which banned the mailing of "obscene, lewd, lascivious, or filthy" material through the U.S. Postal Service. Over the ensuing decades, judicial interpretations of obscenity were dispensed with wide latitude and covered any publications or materials dealing with sex and birth control. ${ }^{23}$

The Comstock laws alongside Prohibition produced much caustic editorial fodder as some Progressives chafed at both the regulations governing alcohol and Comstockery's restrictions on free speech. Famed newspaper editor Arthur Brisbane wrote in his syndicated "Today" column of the ironies of unlawful alcohol and illegal birth control.

What about the prohibition law?... A man in the west was accused of having wine in his house. Nobody was drunk, but agents broke in and killed his wife. Is there a different law for Park Avenue, New York? A New York birth control clinic is raided, five women locked up. The law says you mustn't give information about birth control ... Everybody knows that prosperous women get without trouble all the birth control information they want from able, respectable doctors. However, in this land of equality, there is always a difference between the rich and the poor, whether in prohibition or birth control. ${ }^{24}$
In Margaret Sanger's Birth Control Review, she too mocked the double standard of Americans breaking both alcohol and birth control laws "with equal vigor," but even more importantly, noted there was a gendered price for women seeking reliable medical information on contraception.

When laws are passed that men (or some men) don't like, they have so many wonderful ways of evading them. Just think of it ... Aeroplanes at their service ... Hotel proprietors with bureau drawers at their disposal. Automobile makers who will manufacture trucks to hold both gasoline and booze ... All at the service of rebellious law breaking men who want to get comfortably drunk. And when women want medical information, safe, sane, decent contraceptive information to protect their health and their homes and their children - they are hounded, vilified, jailed, fined, trapped ... They have ... no aeroplanes, automobiles ...hotels ... There you are. A nice clear cut contrast in law breaking. ${ }^{25}$

Other women's rights advocates also noted the hysteria of purity reformers' restrictions on both sexual rights and the personal choice to use alcohol. As one editorial put it, "Grandma was a pessimist about human nature. It is pleasant to reflect that her granddaughters today in increasing numbers, have enough respect for the race to believe that prohibition repeal and legalized birth control may be risked without a Saturnalia of promiscuous love making and drunkenness as the inevitable result." 26

Yet the overlapping politics of alcohol reform and the birth control movement often resulted in complex divisions. For example, the sympathy exhibited toward "fallen women" by temperance supporters and members of the WCTU did not necessarily extend to supporting Sanger's movement. The WCTU had its own Department for the Promotion of Purity in Literature and Art, which supported censorship of materials deemed immoral, while the larger organization worked for stricter prostitution reform laws and to raise the age of sexual consent in nearly every state. ${ }^{27}$ But their concerns about sex and exploitation did not include openly advocating for legal birth control. ${ }^{28}$

Further, anti-Prohibition supporters often framed their stance not through the rhetoric of civil liberties or personal right, but rather by employing the same arguments of home protectionism and anti-immigrant, anti-criminal sentiments that temperance advocates had used for decades. Opponents of prohibition claimed that the Eighteenth Amendment, far from improving society, had merely provoked a crime wave, 
created a criminal class, increased prostitution, and decreased young people's respect for the law. Women, especially those who joined the Women's Organization for National Prohibition Reform (founded in 1929), used anti-criminal and anti-immigrant rhetoric to argue for the repeal of prohibition but not for the legalization of birth control. ${ }^{29}$ Indeed, anti-birth control views fit neatly into the framework of amendment repeal. As one president of a local chapter of the Hibernian Society declared, Prohibition's increasing crime and lawlessness had "ill effects on our young as similar to the way that temperance reformer Carrie Nation had smashed saloons with her axe, pointing out that "A few women suffer from the effects of the abuse of alcohol ... But all women ... are touched by the problem of Birth Control." 32

Aside from these kinds of emotional appeals long familiar to temperance advocates, Sanger also focused on the problems presented by alcohol as a disseminator of poverty and vice, with the solution being not temperance, but legal contraception. One story reprinted in the Review told of a woman who had a "down-at-

\section{The movements for temperance, anti-Prohibition, and birth control may have diverged in terms of political framing, but they nonetheless shared a focus on eugenics as a central underpinning. Margaret Sanger and her supporters naturally incorporated the anti-alcohol views present in the philosophy of voluntary motherhood to strengthen their case for the legal distribution of contraceptive literature, and to underscore the link between the need for birth control, the social costs of alcohol, and eugenic improvement.}

people" but also that "Birth control will ruin the nation unless the practice is stopped at once." 30

The movements for temperance, anti-Prohibition, and birth control may have diverged in terms of political framing, but they nonetheless shared a focus on eugenics as a central underpinning. Margaret Sanger and her supporters naturally incorporated the antialcohol views present in the philosophy of voluntary motherhood to strengthen their case for the legal distribution of contraceptive literature, and to underscore the link between the need for birth control, the social costs of alcohol, and eugenic improvement. From the beginning of its run, the Birth Control Review published hundreds of pleading missives from women with alcoholic and abusive husbands, begging for information on birth control. These women were part of the "deserving poor" - dependent mothers and children whose husbands and fathers had left them bereft of support and were thus worthy of public aid. Sanger also reported on the "relation between large families and drunkenness" at her neighborhood birth control meetings. She argued that increased drinking occurred among women who could not control the number of children they bore and that they "[get] discouraged with constant working and trying to feed many mouths on the same amount of money that she [gets] from her 'chap' when there were but two or three to feed." ${ }^{31}$ She cast her fight for birth control heel, hungry, out-at-elbow" childhood, growing up with a "swarm of others in a tiny cottage." The woman as an adult then began to "[drift] into daily drinking, a weak-willed, weak-souled, weak-bodied woman creature, easy prey for the first half-drunken, acquisitive male." Her husband was away in the First World War, and "before he had been gone a year, there was another child in the four-roomed cottage and another soldier in France who had 'left a little thing behind him." The story concluded with the mother dying and her passel of dirty, hungry children sent to social services. Neatly linking alcoholism, poverty, immorality, and the need for contraception to control the fertility of a woman who could not take care of herself, the tale warned its readers of the consequences of a society rampant with defectives. Sanger explained the need for legalized birth control to prevent people like the woman character of the story from procreating and transmitting indefinitely their insanities and alcoholic predispositions. ${ }^{33}$ As the welfare state solidified in this period, Sanger's apocryphal stories about both deserving mothers and those with bad heredity making poor reproductive choices served as important rhetorical tools in urging the legalization of birth control. This rhetoric was part of larger initiatives designed to improve not only general public health, but to lessen the burdens placed on the system by the delinquent and defective - the undeserving poor. ${ }^{34}$ Birth con- 
trol, promised Sanger, could eliminate these problems before they even happened.

Physicians occasionally questioned Sanger's logic. Dr. Aaron J. Rosanoff explained that he doubted whether birth control was "fully capable" of eliminating the problem of "bad heredity," scoffing that birth control "seems to be employed for other than eugenic reasons by those who from a eugenic standpoint would least need to employ it, and it seems to be the most neglected by those from a eugenic standpoint who would most need to practice it." But he conceded that it was entirely possible that freely available birth control information would help eliminate "syphilis, alcoholism and drug addictions." ${ }^{35}$ Other doctors insisted that Sanger was right, and that birth control was a crucial prophylactic tool in preventing the births of the feebleminded to drunkard parents. ${ }^{36}$ These medical debates aside, by framing the need for birth control through both the moral and eugenic politics of alcohol use, Sanger was able attract enormous support for her American Birth Control League by the end of the 1920s, and firmly link in the public mind the use of birth control with the prevention of social degeneration, disability, and vice. In other words, by making the link between alcohol and birth control explicit in their propaganda literature, it furthered public support for birth control in a way the deemphasized the radical feminist origins of the movement and instead linked it to broader conceptions of public health.

Examined together, the temperance and birth control movements demonstrate the increasing scientifically-oriented and professionalized nexus of Progressive reform causes. In particular, white, middle-class women reformers stood at the forefront of each of these movements and popularized support for their them by drawing on eugenics, whose doctrines fit neatly into the broader Progressive milieu of social improvement. Moreover, women's central roles in these reform causes were almost certainly a result of eugenics' longstanding emphasis on women's right to choose fit mates and their superior ability to observe and improve familial relationships. ${ }^{37}$

Eugenics thus cemented via the weight of scientific authority the far longer history of American women's reform efforts, whose roots were in antebellum domestic moral reform and the abolitionist movement. Crucially, both anti-alcohol and pro-birth control stances aligned supporters with their causes by emphasizing the preservation of home and family above all. Eugenics provided the scientific and medical backing for much older sentiments about maternal and family affection as the solution for regenerating and improving broader social health. Although temperance had long been part of arguments for moral reform, the birth control movement's ideological pivot toward eugenics and public health was key to incorporating it into the canon of domesticity and Progressive benevolence. The debate over alcohol's effects served as a critical entry point and ultimately altered the nature of concomitant arguments over contraception's role in society.

Yet aligning birth control and anti-alcohol stances would come with a cost for women's rights and the rights of the disabled throughout the remainder of the twentieth century. Women's moral responsibility for their health behavior and the health outcomes of their fetuses and babies would invite medical scrutiny and continued broad policing by the state of their reproductive lives. By stigmatizing alcoholism as a preventable moral disease and prescribing birth control as the solution, women (and not men) were ultimately responsible for the number and health of the children they bore, and for their economic circumstances. Further, as medical understandings of intellectual disability and fetal alcohol syndrome developed later in the twentieth century, the moral panic surrounding women, alcohol, and contraception only intensified.

The making of fetal alcohol syndrome (FAS) reformatted early twentieth-century eugenic concerns about alcohol and babies into a more modern diagnosis. Research on the relationship between alcohol and heredity declined after the lifting of Prohibition laws, and instead focused on alcohol's role in human disease and the science of addiction. ${ }^{38}$ At the same time, research on contraceptive drugs and methods ramped up considerably beginning in the early 1940 s and can be considered part of the popular twentieth-century scientific interest in population and maternal-child health. Unlike earlier in the century, the two research areas, alcohol and reproductive health, were kept relatively separate, and many experts had come to dismiss the idea that alcohol could affect offspring directly. It was not until the 1970 s, when FAS was officially named, that physicians and researchers began to again explore the question of how and why alcohol damages a fetus, and what, if anything, should be done about it. As Janet Golden has noted, FAS came to be understood as both "a description of the spectrum of effects resulting from heavy alcohol exposure in utero and as a way of naming the behavior of pregnant women." 39 The courts, Congress, the FDA, physicians and the public debated the intersections of abortion and disability rights, the rights and obligations of pregnant women, and the right to privacy and choice in women's individual lives, even as teratogens (including alcohol) attracted increasing research scrutiny.

Birth control was part of these debates but served as a less controversial aspect, since by the time FAS 
emerged as a diagnosis, it was legal for all adult women to obtain contraception regardless of marital status. Medical recommendations for avoiding unwanted pregnancy harmonized with the advice on safe drinking and how to avoid fetal alcohol syndrome. But in 2016, the Centers for Disease Control and Prevention's new guidelines for sexually active women presented a new angle. Women who did not use birth control should refrain from drinking altogether, as there is no known safe amount of alcohol to drink while pregnant. In response, critics used the words "puritanical" and accused the CDC of promoting the idea that women could not be responsible or trusted. Similar concerns animated the response to the 2021 guidance released by the WHO.

In the story of the long relationship between alcohol use and reproductive health, the WHO and the CDC's guidelines for alcohol and pregnancy serve as an interesting foil to the rhetoric of the 1920s. Rather than using alcohol as an entry point to further the acceptance or legalization of contraception, instead contraception is now the requirement for women's alcohol use. And yet, though separated by a century, the exhortations of both campaigns share a similar goal. In both cases, the rhetoric of fetal health places the responsibility on the woman for a healthy pregnancy and the enduring duty to place fetal life above her own, even when that life is nothing more than a future possibility.

The recent guidelines thus reveal an important shift in the thinking on fetal rights. In the 1920s, the literature on temperance, anti-Prohibition programming, and birth control all emphasized the general betterment of the race if each agenda were met. Although women activists also used these individual movements to further their political and social gains, ultimately the strength of the anti-alcohol, anti-Prohibition, and pro-contraception movements rested not on the advancement of individual rights for women or the disabled but rather the broader health of the public. ${ }^{40}$ All three campaigns emphasized how social morality would improve, people would be healthier, and the overall strength of the nation would grow.

However, for the past several decades, the emergence of the fetus as an individual subject with equal rights has fundamentally altered medical and public health debates on pregnancy and teratogenic substances like alcohol. Assigning the rights of personhood to fetuses in the womb not only allows the perpetuation of historic arguments about women's ultimate responsibility for the effects of their moral choices surrounding their unborn children, but also positions arguments for women's freedom of choice (such as in alcohol use) in competition with abortion rights and the rights of the disabled. As Katha Pollitt phrased it in her famous essay for The Nation just as the abortion wars of the 1990s began to escalate, "As the 'rights' of the fetus grow and respect for the capacities and rights of women declines, it becomes harder and harder to explain why ... a woman can choose an abortion but not vodka." ${ }^{11}$ The recent public health guidelines on birth control, pregnancy, and drinking contribute to these ongoing debates about fetal personhood, as part of a legal and social dilemma that pits women's rights directly against the rights of other groups.

Further, the historical relationship between alcohol legislation and birth control and abortion politics reveals new insights into contemporary debates about labor force participation, malingering, and the nature of alcohol and drug dependency. Over the last several decades, work requirements under various administrations were tightened for welfare qualification, and the emphasis beginning in the 1990s on transitioning from welfare to work reemphasized recipients' personal responsibility rather than the structural barriers affecting their employment status, family stability, and health. These policy deliberations also echo far older ideas about gender and motherhood that were present in the late nineteenth and early twentieth century. The emphasis on marriage, sexual abstinence, and women's responsibility for the family remains central to federal programs like Temporary Assistance for Needy Families (TANF) which has incentives for two-parent families and punishments for parents who abuse drugs or alcohol or who otherwise do not comply with work and child support requirements. In other words, alcohol use, pregnancy, and single motherhood remain hot-button issues in the decisions surrounding who "deserves" welfare.

Examining how these ideas developed in the past and in conversation with each other can be useful indicators for both reproductive and future welfare policy initiatives. Progressive Era reformers, birth control advocates, and pro and anti-Prohibition factions created concrete political strategies and campaigns, often in response to each other, that deliberately exploited deep anxieties about gender, race, and class in America. Although the rhetoric has changed and flattened, the animating core of anxiety remains in the oftenconfusing modern vocabulary around alcohol, pregnancy, and responsibility. As we seek more effective public health messaging on alcohol and its risks, and a more efficient welfare system that improves peoples' lives, policymakers' knowledge of these historic issues is not just nice to have, but a critical component of improvement in delivery and outcomes. 
Note

The author has no conflicts of interest to disclose.

\section{References}

1. "The WHO Alcohol-Pregnancy Warning for Childbearing Women Overlooks Men, As Usual," NBC News, June 21, 2021, available at <https:/www.nbcnews.com/think/opinion/whoalcohol-pregnancy-warning-childbearing-women-overlooksmen-usual-ncna1271690> (last visited July 5, 2021); Q. Zhou, L. Song, J. Chen J, et al., "Association of Preconception Paternal Alcohol Consumption With Increased Fetal Birth Defect Risk," JAMA Pediatrics, available at <https://jamanetwork. com/journals/jamapediatrics/fullarticle/2778779> (last visited July 16,2021 ).

2. M.L. McClellan, Lady Lushes: Gender, Alcoholism, and Medicine in Modern America (Camden: Rutgers University Press, 2017): at 29-30.

3. M. R. Waggoner, The Zero Trimester: Pre-Pregnancy Care and the Politics of Reproductive Risk (Oakland: University of California Press, 2017)

4. L.A. Schmidt and D. McCarty, "Welfare Reform and the Changing Landscape of Substance Abuse Services for LowIncome Women," Alcoholism: Clinical and Experimental Research 24, no. 8 (2000): 1298-1311.

5. Quoted in B.C. Jones, "Prohibition and Eugenics, 1920-1933," Journal of the History of Medicine and Allied Sciences 18 (1963): 158-117, at 158 .

6. L.M.N. Stevens, "The Work of the National Woman's Christian Temperance Union," The Annals of the American Academy of Political and Social Science 32 (1908): 508-512.

7. Woman's Standard (Waterloo, IA) 3, no. 1, (1888): 2.

8. Stevens, supra note 6.

9. Woman's Signal: A Weekly Record and Review Devoted to the Interests of Women in the Home and in the Wider World (London) 6, no. 155 (1896): 395

10. A. Wittenmyer, History of the Woman's Temperance Crusade: A Complete Official History of the Wonderful Uprising of the Christian Women of the United States Against the Liquor Traffic, Which Culminated in the Gospel Temperance Movement (Boston: J.H. Earle, 1882): at 774.

11. Union Signal (Chicago, IL) 9, no. 10 (1883): 10.

12. F. Galton, "Hereditary Talent and Character," Macmillan's Magazine 12 (1865): 157-166, continued in 12 (1865): 318-327. As noted in D.J. Kevles, In the Name of Eugenics: Genetics and the Uses of Human Heredity (Berkeley: University of California Press, 1985).

13. F. Galton, Inquiries Into Human Faculty and Its Development (Macmillan, 1883). For a good summary of how Galton specifically developed his interest and theory in eugenics, see N.W. Gillham, "Sir Francis Galton and the Birth of Eugenics," Annual Revier of Genetics 35, no. 1 (2001): 83-101; F. Galton, "Eugenics: Its Definition, Scope, and Aims," American Journal of Sociology 10, no. 1 (1904): 1-25.

14. P.A. Lombardo, "The Power of Heredity and the Relevance of Eugenic History," Genetics in Medicine 20 (2018): 1305-1311.

15. Abbeville Press and Banner (Abbeville, SC), April 25, 1900, at 7 .

16. W. Healy, The Individual Delinquent: A Textbook of Diagnosis and Prognosis for All Concerned in Understanding Offenders (Boston: Little, Brown, and Company, 1915): at 151.
17. Birth Control Review, August 1922

18. See Jones, "Prohibition and Eugenics," supra note 5.

19. J.L. Golden, Message in a Bottle: The Making of Fetal Alcohol Syndrome (Cambridge: Harvard University Press, 2006): at 23.

20. S.M. Rensing, Feminist Eugenics in America: From Free Love to Birth Control, 1880-1930, Ph.D. dissertation, University of Minnesota (2006): at 80-82.

21. M.H. Hunt and the Women's National Christian Temperance Union, A Temperance Physiology for Intermediate Classes and Common Schools (New York and Chicago: A.S. Barnes \& Company, 1884): at 159

22. See Hunt, supra note 21.

23. For more on Comstock see N.K. Beisel, Imperiled Innocents: Anthony Comstock and Family Reproduction in Victorian America (Princeton, NJ: Princeton University Press, 1998); T.J. Gilfoyle, City of Eros: New York City, Prostitution, and the Commercialization of Sex, 1790-1920 (New York: W. W. Norton \& Company, 1994).

24. The Bee (Danville, VA), April 17, 1929, at 4.

25. Birth Control Review, January 1919.

26. The Pittsburgh Press, January 3, 1933, at 23.

27. A. Parker, "Hearts Uplifted and Minds Refreshed': The Woman's Christian Temperance Union and the Production of Pure Culture in the United States, 1880-1930," Journal of Women's History 11, no. 2, 1999: 135-158.

28. A. Parker, Purifying America: Women, Cultural Reform, and Pro-Censorship Activism, 1873-1933 (Urbana: University of Illinois Press, 1997).

29. K. D. Rose, American Women and the Repeal of Prohibition (New York: New York University Press, 1995).

30. Des Moines Tribune, August 13, 1929, at 6.

31. Birth Control Review, August 1920.

32. Birth Control Review, March 1919.

33. Birth Control Review, March 1925.

34. M. Ladd Taylor, Fixing the Poor: Eugenic Sterilization and Child Welfare in the Twentieth Century (Baltimore: Johns Hopkins University, 2017): at 13-14.

35. Birth Control Review, April 1926.

36. Birth Control Review, October 1924.

37. As noted by E.J. Larson in "The Finest, Most Womanly Way:' Women in the Southern Eugenics Movement," American Journal of Legal History 39, no. 2 (1995): 119-147, at 121, paraphrasing H.H. Goddard, "The Binet Tests in Relation to Immigration," Journal of Pscyho-Asthenics 18, no. 2 (1913): 105-107, at 106

38. See Golden, supra note 19: at 30.

39. See Golden, supra note 19: at 16

40. Even birth control, although explicitly linked with the feminist movement, did not achieve legalization based on women's right to make their own choices, but because the courts elevated physicians' rights to practice medicine as they saw fit. The Griswold v. Connecticut case cited married couples' privacy rights but cited their decision to use birth control as one to be made in consultation with their physician.

41. K. Pollitt, "Fetal Rights: A New Assault on Feminism," The Nation, March 26, 1990, at 409. 